\title{
Terror and terroir
}

The winegrowers of the Languedoc and modern France

\section{ANDREW W. M. SMITH}

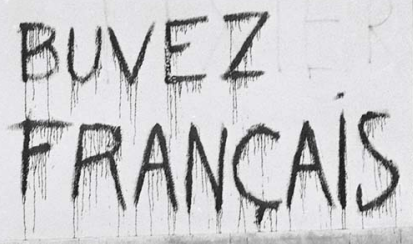

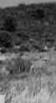

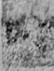

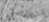
4

(1)

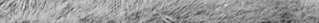

(x) atrof

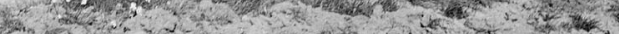

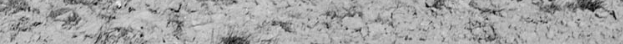
Fow

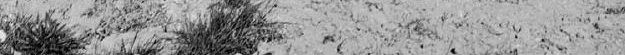

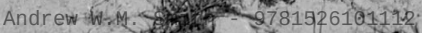

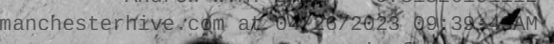

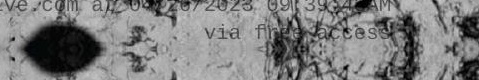


Studies in

Modern French History

$\longrightarrow$

Terror and terroir

\section{MANCHESTER} 1824

Manchester University Press 


\section{Studies in \\ Modern French History \\ Edited by \\ David Hopkin and Máire Cross}

This series is published in collaboration with the UK Society for the Study of French History. It aims to showcase innovative short monographs relating to the history of the French, in France and in the world since c.1750. Each volume speaks to a theme in the history of France with broader resonances to other discourses about the past. Authors demonstrate how the sources and interpretations of modern French history are being opened to historical investigation in new and interesting ways, and how unfamiliar subjects have the capacity to tell us more about the role of France within the European continent. The series is particularly open to interdisciplinary studies that break down the traditional boundaries and conventional disciplinary divisions.

Titles already published in this series

Emile and Isaac Pereire: Bankers, Socialists and Sephardic Jews in nineteenthcentury France Helen Davies

Catholicism and children's literature in France: The comtesse de Ségur (1799-1874) Sophie Heywood

Aristocratic families in republican France, 1870-1940 Elizabeth C. Macknight

The republican line: Caricature and French republican identity, 1830-52 Laura O’Brien

The routes to exile: France and the Spanish Civil War refugees, 1939-2009 Scott Soo

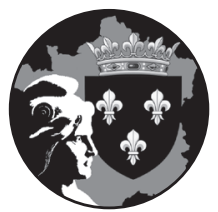

The Society for the Study of French History 


\section{Terror and terroir}

\section{The winegrowers of the Languedoc and modern France}

ANDREW W. M. SMITH

Manchester University Press 
The right of Andrew W. M. Smith to be identified as the author of this work has been asserted by him in accordance with the Copyright, Designs and Patents Act 1988.

Published by Manchester University Press Altrincham Street, Manchester M1 7JA www.manchesteruniversitypress.co.uk A catalogue record for this book is available from the British Library

Library of Congress Cataloging-in-Publication Data applied for

ISBN 9781784994358 hardback

First published 2016

The publisher has no responsibility for the persistence or accuracy of URLs for any external or third-party internet websites referred to in this book, and does not guarantee that any content on such websites is, or will remain, accurate or appropriate.

Typeset by

Servis Filmsetting Ltd, Stockport, Cheshire 